\title{
Customary Forests in West Papua: Contestation of Desires or Needs?
}

\author{
Antoni Ungirwalu ${ }^{1,}{ }^{*}$, San Afri Awang ${ }^{2}$, Yubelince Y. Runtuboi ${ }^{1}$, Mariana Y. Peday ${ }^{1}$, Jonni \\ Marwa $^{1}$, Bustar Maitar ${ }^{3}$, Agustinus Murdjoko ${ }^{1}$ and Sepus M Fatem ${ }^{1}$ \\ ${ }^{1}$ Faculty of Forestry, Papua University, Gunung Salju Street, Manokwari, West Papua 98314, Indonesia; \\ a.ungirwalu@unipa.ac.id; y.runtuboi@unipa.ac.id; m.peday@unipa.ac.id: jonnimarwa@gmail.com; \\ agustinus.murdjoko.papua@gmail.com; sepus_fatem@yahoo.com . \\ 2 Faculty of Forestry, Gadjah Mada University, Agro Street No. 1 Bulaksumur, Yogyakarta 55281, \\ Indonesia; awangzaza02@gmail.com \\ 3 Yayasan EcoNusa, Jl. Maluku No.35, RT.6/RW.5, Gondangdia, Kec. Menteng, Kota Jakarta Pusat, Daerah \\ Khusus Ibukota Jakarta 10350, Indonesia. bmaitar@gmail.com \\ * Correspondence author: a.ungirwalu@unipa.ac.id ; Tel.: +62-81344123400
}

\begin{abstract}
The challenge of integrating ecological, economic and social aspects of forest management is still a critical issue among stakeholders who agree on community-based forestry and the rights of indigenous peoples. In West Papua, the contrast of abundant natural resources with serious social inequalities and structured poverty is a continuing challenge for implementing a social forestry program. The process of establishing customary territories in West Papua is an important milestone in recognising its community entities. Is this scheme definitively able to answer the interests of access and management of indigenous peoples? This can help in achieving the sacred goal of protecting $70 \%$ of the forest area. This paper examines the dynamics of forest management in West Papua by the parties in customary forests. The low area designated for customary territories in West Papua, which has only reached 2,554.2 hectares, and the absence of a decree on the existence of customary forests is a form of injustice to the interests of local communities. The social forestry acceleration program intended to end the uncertainty surrounding customary forests is still in process. The roles of both on-site and off-site parties have not been optimal in realising customary forests in West Papua due to the complex and incomplete translation process at the site level. The results of the review show that interest is still focused on achieving an indicative-annual figure, which is still dominated by the village forest scheme. Hopefully, this year's acceleration of customary forests will become a milestone in West Papua, based on mutual need and desire.
\end{abstract}

Keywords: Customary forest; stakeholder; West Papua; social forestry

\section{Introduction}

The United Nations Conference on Environmental and Development (UNCED) popularised a discourse that emphasises civil society participation in the management of natural resources (Maryudi, 2015). This discourse is marked by the increasing use of the terms "stakeholder" and "participation" which are associated with a bottom up approach. The most important parties include the government (state) as the dominant actor, as well as local customary, or adat communities, NGOs, universities, and private parties who are directly or indirectly involved in forest management (Awang, 2008; Arts et al., 2010).

In the context of adaptive forest management, which is an approach to simultaneously manage and learn about natural resources by adjusting to the dynamics of social and ecological systems and the interactions between them (Boo and Wiersum, 2011), stakeholder engagement means bringing all parties together in learning to deal with complexity. One aspect of this complexity is the challenge of integrating the ecological, economic and social aspects of forest management. In West Papua, this means balancing the exploitation and conservation of abundant natural resources within a context of serious social inequality and structured poverty (Pitoyo et al., 2019). 
Data from the Indonesian Center for Statistics from 2011-2018 shows that the Provinces of Papua and West Papua consistently show the highest poverty rates in Indonesia. This fact gained serious attention from the Joko Widodo administration, which issued Presidential Instruction (Inpres) Number 9 of 2017 concerning the acceleration of welfare development in Papua and West Papua Provinces (Tanah Papua). This was followed by Presidential Decree (Keppres) Number 20 of 2020 concerning the Integrated Coordination Team for the Acceleration of Welfare Development in Papua and West Papua Provinces. In the 2020 national development plan, the Ministry of Environment and Forestry prioritized poverty alleviation through the Social Forestry program, including projects related to customary forests.

To what extent do these efforts address the discourse of local (customary) communities, natural resource management, and poverty itself? Several studies have revealed that forest management that does not address these issues, will encounter many obstacles and end in failure (Harrison et al., 2020; ws \& Missingham, 2009; Rickenbach et al., 2005).

This statement frames the contestation of forest management in the two Papuan provinces. The subsequent question is whether customary forests in the Papua region are conceived solely to address the needs of civil society (indigenous people) or is it an initiative designed for the needs of other stakeholders? This study will explore the intersection of forest management in the Papua region.

As previously discussed by Ragandhi et al. (2021), state-initiated community-based forest management schemes tent to grant rights rather than facilitate the appropriate mechanism for distributing benefits to local communities. Contextually, linking the needs and desires of the central and regional governments related to top-down customary community-based forest management still raises many fundamental questions related to policies that have been implemented to date. Have they answered the basic needs themselves? This perspective is discussed below to determine the future prospects for developing customary forests in West Papua.

\section{Actors and interests in Forest Management}

A multistakeholder decision-making process is a necessity pre-condition for successful adaptive management (Purnomo, 2012). Stakeholder identification and analysis is based on the institutions, policies and issues of interest, from the global o the local level (see Table 1).

Table 1. Identification of forest management interests based on institutions, policies, and issues of in the Papua region

\begin{tabular}{|c|c|c|c|c|}
\hline No & Institution & Multi-stakeholder & Forest Management Policy & Issues of Interest \\
\hline 1 & $\begin{array}{l}\text { Global and } \\
\text { International }\end{array}$ & $\begin{array}{l}\text { UNESCO, UNCED, } \\
\text { ILO, ITTO, Foreign } \\
\text { governments, } \\
\text { international NGOs }\end{array}$ & $\begin{array}{l}\text { Focus on environment, climate } \\
\text { adaptation, and mitigation of } \\
\text { emissions levels }\end{array}$ & $\begin{array}{l}\text { Sustainable forest } \\
\text { management, } \\
\text { Reducing Emissions } \\
\text { from Forest } \\
\text { Degradation and } \\
\text { Deforestation (REDD } \\
+ \text { ) }\end{array}$ \\
\hline 2 & National & $\begin{array}{l}\text { Central } \\
\text { government, NGOs } \\
\text { (AMAN) }\end{array}$ & $\begin{array}{l}\text { Focus on economic growth, } \\
\text { civil society and markets }\end{array}$ & $\begin{array}{l}\text { Revision of Law no. } \\
41 / 1999, \text { MK } 35, \\
\text { customary forests, } \\
\text { and oil palm } \\
\text { expansion }\end{array}$ \\
\hline 3 & Regional & $\begin{array}{l}\text { Ministry of Forestry, } \\
\text { Social Forestry } \\
\text { Working Group } \\
\text { (Pokja PS), NGOs }\end{array}$ & $\begin{array}{l}\text { Focus on Welfare, Community- } \\
\text { Based Forest Management } \\
\text { (CBFM): Social Forestry and } \\
\text { Forest Management Units } \\
\text { (FMUs/KPH) }\end{array}$ & $\begin{array}{l}\text { P.83/2016, FMU } \\
\text { model; P.21 / } 2019 \\
\text { and village funds }\end{array}$ \\
\hline 4 & Off-site & $\begin{array}{l}\text { Local government, } \\
\text { FMU, private sector, }\end{array}$ & $\begin{array}{l}\text { Focus on forest management } \\
\text { authority, designation of }\end{array}$ & $\begin{array}{l}\text { Law 32/2014, Local } \\
\text { government decree }\end{array}$ \\
\hline
\end{tabular}




\begin{tabular}{|c|c|c|c|c|}
\hline No & Institution & Multi-stakeholder & Forest Management Policy & Issues of Interest \\
\hline & & $\begin{array}{l}\text { NGOs, local } \\
\text { universities, } \\
\text { Indigenous Peoples } \\
\text { Institution } \\
\text { (IPI/LMA), Regional } \\
\text { People's } \\
\text { Representative } \\
\text { Council (RPPC/DAP), } \\
\text { Papua People's } \\
\text { Assembly } \\
\text { (PPA/MRP) }\end{array}$ & $\begin{array}{l}\text { Conservation Province, } \\
\text { Provincial / Regency Spatial } \\
\text { plans (RSP/RTRW). }\end{array}$ & $\begin{array}{l}\text { re Conservation } \\
\text { Province, Customary } \\
\text { Forests, Village } \\
\text { Forests. FMU Models }\end{array}$ \\
\hline 5 & On-site & $\begin{array}{l}\text { Papuan Ethnic } \\
\text { Communities }\end{array}$ & $\begin{array}{l}\text { Focus on subsistence } \\
\text { agriculture and recognition of } \\
\text { management rights }\end{array}$ & $\begin{array}{l}\text { Access and } \\
\text { prosperity to forest } \\
\text { management }\end{array}$ \\
\hline
\end{tabular}

Source: Adapted from Ungirwalu, 2018

The issue of regional forest management is inseparable from more global concerns about the environment, and particularly about climate change (O'brien et al., 2007). Over twenty international agreements involving forty world organizations address deforestation and forest degradation; however, not all of these agreements address forest resources, such as local and indigenous peoples' rights (Maryudi, 2015). On a global scale, the issue of local and indigenous peoples was highlighted at the World Forestry Congress III in Jakarta in 1978, under the theme "forests for the people".

The focus of community-based forest natural resource management received great attention when the WTO removed Indonesia from the list of developing countries in February, 2020. This had a direct and significant impact on global funding for the program, especially in addressing the impacts of climate change and social inequality in Indonesia.

Maini (2003) offered a typology based on the United Nations Conference on Environment and Development in 1992. At that time, Indonesia was still classified as a developing country, based on its low per capita income. Indonesia's forest policies at the time were focused on enhancing economic growth (Fig 1.). Synergy among national interests is important in implementing local community-based forest management objectives.

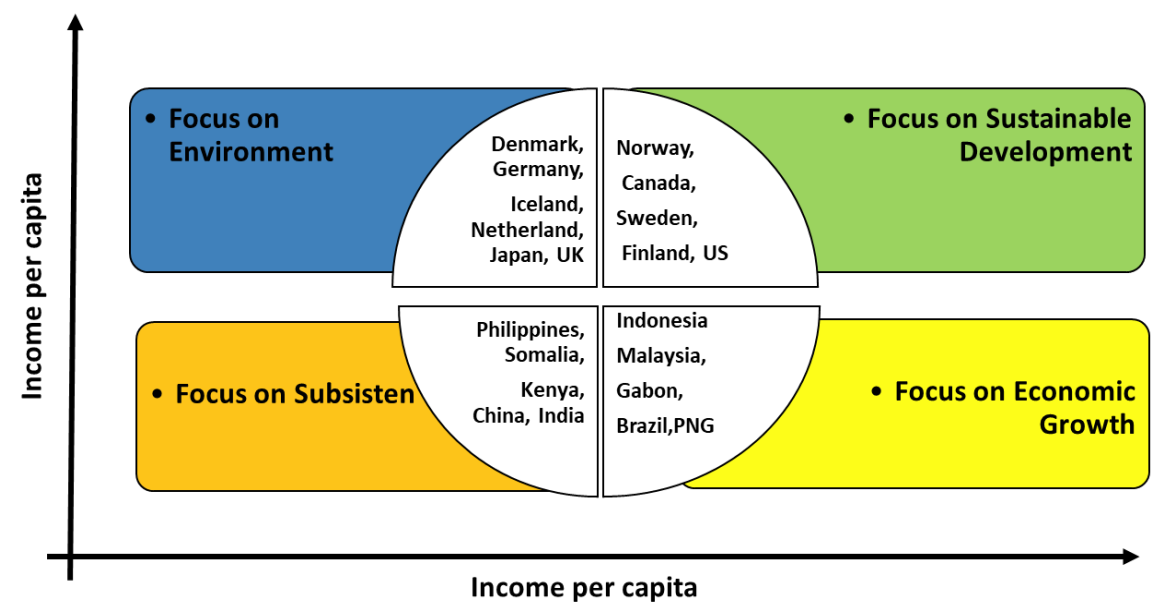

Figure 1. State typology and forest policy agenda (Maryudi, 2015)

Is Tanah Papua worthy of being included in the category of developed country territory? Tanah Papua consists of two administrative regions, namely the province of West Papua and Papua; both are considered among the poorest provinces in Indonesia (West Papua Province is ranked 33rd, and Papua is ranked $34^{\text {th }}$, with the highest poverty index among Indonesia's 34 provinces) (BPS, 2018). In 2015 the PDRB per capita of West Papua Province was IDR 72.50 million. The amount increased 
to Rp. 87.9 million in 2019, an increase of 21.8 percent in 5 years. Until this decade, forest management was largely carried out by local communities and focused on meeting their daily needs (subsistence), in contrast to state interests which focus on economic growth.

In addition to these economic and social considerations, ecological aspects are a most important part of the identity of indigenous peoples in Tanah Papua. The region's forests contain abundant natural resources. They provide habitat for 13,334 plant species, 602 bird species, 125 mammal species, and 223 reptile species (Cámara-Leret et al., 2020). Local communities that depend on the forest are diverse and multicultural, speaking 269 local languages (Marshall et al., 2007). On the other hand, the influx of massive investment, especially in oil palm development, greatly affects biodiversity and indigenous peoples' livelihoods and access to the forest (Runtuboi et al., 2021).

The interest of the regional government, in this case the provincial governments of Papua and West Papua, is to improve the welfare of its people. The vision of the West Papua Province's MidTerm Development Plan (RPJMD) for 2017-2022 is Towards a Safe, Prosperous, and Dignified West Papua. Meanwhile, the Papua Province RPJMD 2018-2022 promotes the theme of a Just, Awakened, Independent and Prosperous Papua. The aspects of justice and welfare would presumably be measured at the site level, where natural resource management planning based on indigenous peoples' welfare can be evaluated. However, thus far it is easier for the private sector to gain access and rights to cultivate, as evidenced in an analysis of the spatial map of the area. In contrast, it is difficult for communities to secure recognition for their lands. This is a serious challenge, and is especially apparent in the ongoing revisions to West Papua's land use planning document (RTRW$\mathrm{PB})$.

As a concrete action to balance the interests of the state with the needs of indigenous peoples, in October 2015 the Governor of West Papua declared West Papua as a "conservation province." The Conference Communique of the 2018 International Conference on Biodiversity, Ecotourism and Creative Economy (ICBE) was subsequently signed by the Provinces of Papua and West Papua. The Communique (known as the Manokwari Declaration) focused on Sustainable Development Based on Indigenous Areas in Tanua Papua, emphasizing the two Province's commitment to a common vision of "Peaceful Tanah Papua, Sustainable and Dignified". Following the Manokwari Declaration (Cámara-Leret et al., 2019), districts such as Tambrauw made similar policy pronouncements (Fatem et al., 2020). Since 2017, West Papua Province has also proposed a parliamentary initiative to draft a Special Regional Regulation (Raperdasus) on Indigenous Papuans and Customary Territories/Customary Communities and their Traditional Rights. Furthermore, in 2018 the Governor of West Papua drafted a Regional Regulation (Raperda) on Sustainable Development, also focused on the rights of indigenous peoples.

The central government, in an effort to ensure certainty of access to forests, proposed Ministry of Environment and Forestry Policy Number 83 of 2017 concerning social forestry as a sustainable forest management system in state forest areas or private/customary. In practice, however, the formal community forestry institutions introduced by the government often work independently at the site level (Arts et al., 2012).

In the 2015-2019 Strategic Plan, the government set a target area of 12.7 million hectares for social forestry programs. Nevertheless, compared with the proposed target, performance has increased by $29.02 \%$ from $2018(1,264,156 \mathrm{ha})$. The national area dedicated to social forestry in 2019 can be divided into 274,389.94 Ha Village Forest schemes, 148,887 ha Community Forests, 20,634 ha Community Plantation Forests, 932,470.13 ha Customary Forests, and 212,022.84 ha Partnerships and 551 ha IPHPS (Kementerian Lingkungan Hidup dan Kehutanan, 2019).

The Ministry of Environment and Forestry established the Social Forestry Acceleration Working Group (Pokja PPS) teams in each Province and District. Unfortunately, the PIAPS for the customary forests has not actually been mapped at the site level. This is believed to be primarily a technical issue, namely KLHK's concerns about the methods used for mapping customary lands KLHK is also concerned about claiming customary forests within existing reserves, prior to the announcement of a Decree on Adat Forest Determination (Wibowo et al., 2019). 
Administratively, KLHK combines Tanah Papua with Maluku Provinces into one region, the Maluku-Papua Region. The actual achievements of the Maluku-Papua Regional Social Forestry scheme can be seen in Figure 2.

\section{ACHIEVEMENTS OF THE PAPUA-MALUKU REGIONAL SOCIAL FORESTRY SCHEME IN 2019}

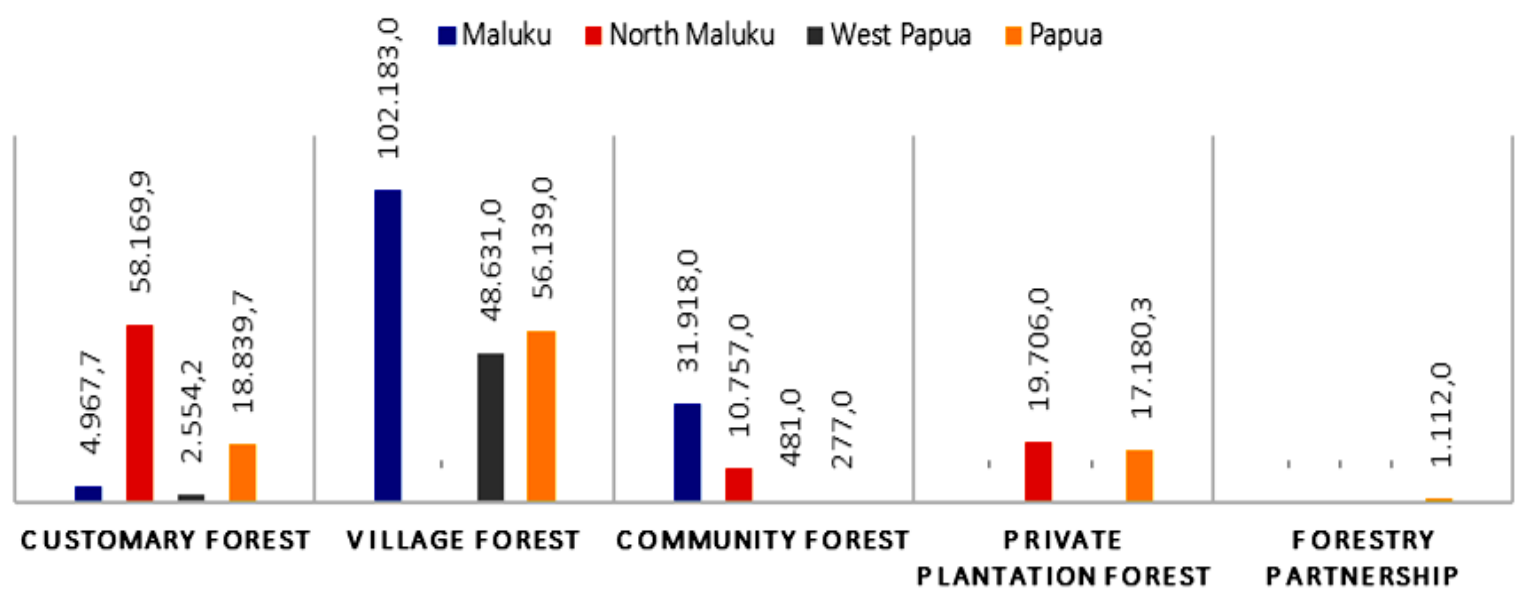

Figure 2. Achievements of Social Forestry in Tanah Papua. [Note: Customary Forest (HA), Village Forest (HD), Community Forest (HKM), Private Plantation Forest (PPF) and Forestry Partnership (KK). Source KLHK, 2019].

The social forestry program uses five distinct implementation schemes: Customary Forest (HA), Village Forest (HD), Community Forest (HKM), Private Plantation Forest (PPF) and Forestry Partnership (KK). For the Maluku-Papua region, the Village Forest program shows the largest area $(255,592.94 \mathrm{Ha})$ with a total of 171 forest village community groups that have received approval. On the other hand, until 2019 not a single Customary Forest management area has received recognition. The social forestry program in West Papua is co-located at the Maluku-Papua Regional Social Forestry and Environmental Partnership Center (Balai PSKL Maluku-Papua). The data in Figure 1. for the achievements of the social forestry program is dominated by the village forest scheme, with limited achievements in terms of customary forests. An evaluation of the national PPS Pokja Team suggested that the acceleration of the social forestry program in Tanah Papua must be developed separately for optimal coordination and accessibility. Tanah Papua, which is larger in territory than Maluku, and with exceptional cultural and ethnic diversity, should be allocated appropriate portion and attention.

Why have so many more Village Forest programs been executed? In contrast to customary forests, Village Forest program has received broad support, because it is relatively easy to implement. The Village Forest typology designated by KLHK encompasses both protection and production forests, ceded to forest-margin communities, to be managed for of 35 years with the possibility of extended permits). In Ministry of Environment and Forestry Regulation No. 83/2016, customary forests are included in the area outside state forest. Submission of applications for customary communities for status of tenure rights/property rights are approved by the Minister of Environment and Forestry.

Data from the Ministry of Environment and Forestry in 2015 shows a total forest cover of 96.5 million hectares, in which Papua has the largest area (34.06 million hectares) with a primary forest cover of 26.15 million hectares (Brearley et al., 2019). Despite this fact, not a single customary territory in Maluku-Papua has yet been approved. Customary Forests covering an area of 129,191.5 hectares in the Maluku-Papua Region is in the initial process stage, but no legal title has been approved.

Regionally, West Papua Province shows 2,554.2 hectares for the Indicative Map of Social Forestry Areas, the smallest area in the Maluku-Papua region (Fig.2). This is in contrast to the Village 
Forest program, which has reached 48,631 ha. Overall, Tanah Papua's forest cover is the largest in Indonesia, but only a tiny portion is earmarked as Customary Forest. The data provides an overview of the process but raises the question of whether forest management policies in Tanah Papua have emphasised community-based management at the site level. In various formal discussions, civil society oganizations, NGO activists, researchers, and campuses have called for mainstreaming social forestry processes, especially those related to the recognition of customary forests.

Several districts have developed regional legal products, but these remain in the first of eight stages of obtaining recognition for customary forests. Recognition of customary communities (Masyarakat Hukum Adat, or MHA), however, is necessary to clarify the administrative boundaries because they do not yet have a communal rights map. This provides an opportunity for the community to obtain legal certainty and rights to customary forests (Hutan Adat, or HA) through a quicker and simpler procedure (CIFOR, 2017a).

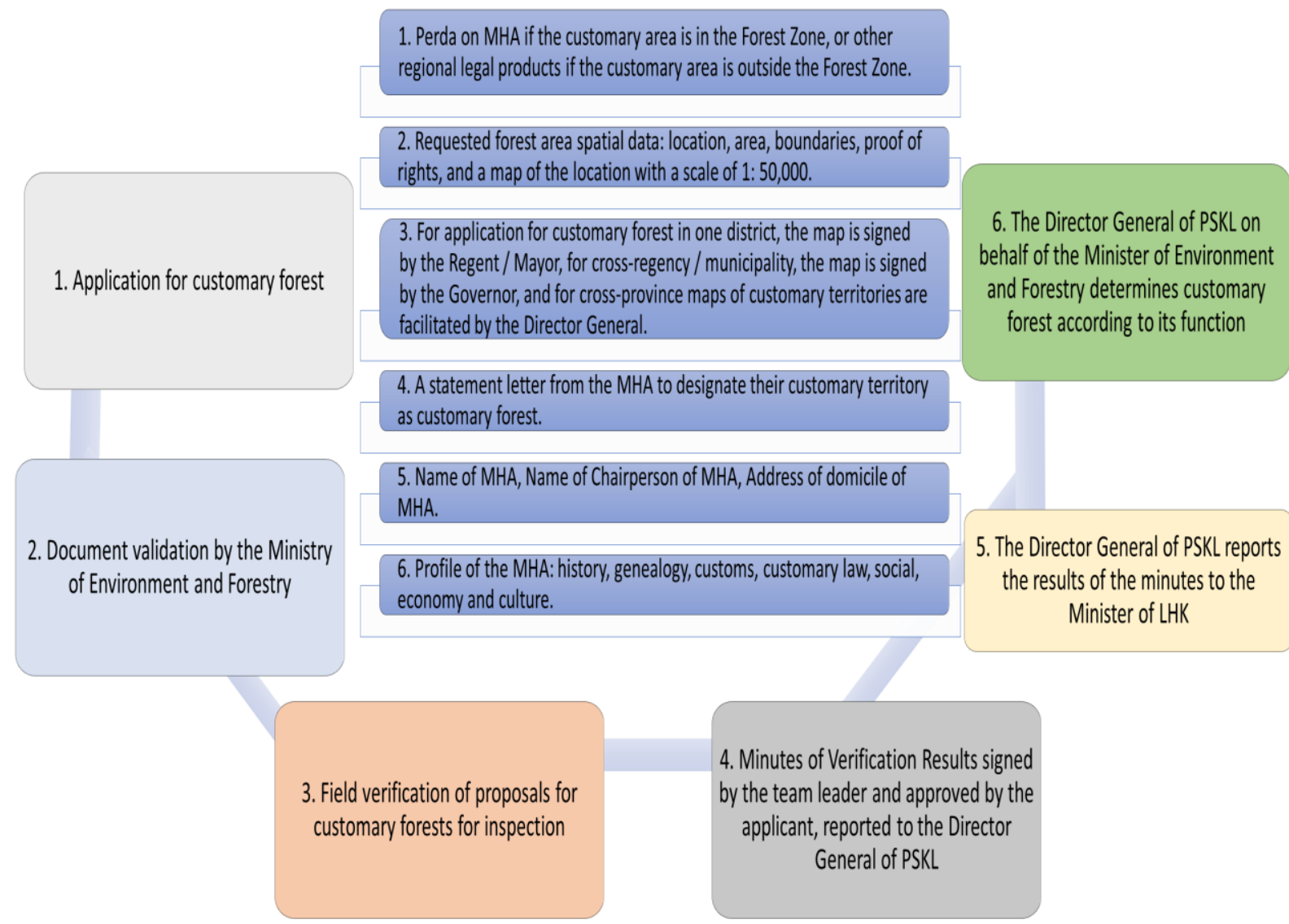

Figure 3. Flowchart of customary forest application (Source: CIFOR, 2017b)

The phrase "respecting the rights of customary communities" in Article 4, Paragraph $3^{1}$ of the Basic Forestry Law must be interpreted more clearly, namely that the state recognises and respects indigenous peoples and their traditional rights, in line with Article 18B Paragraph 2 of the 1945 Constitution. Respect for customary communities in the phrase "insofar as [the community] still exists and their existence is acknowledged," must be interpreted to mean as long as the community still exists and is functioning, because customary law is generally an unwritten, living law, accepted and observed by the people concerned.

\footnotetext{
1 The full language in Article 4, Paragraph 3 of the Basic Forestry Law $(41,1999)$ is as follows: "Forest management by the State shall continue to respect the rights of customary communities, insofar as they still exist and their existence is recognised and does not conflict with national interests."
} 


\section{Customary Forest from The Perspective of The State}

Indonesia's status as a developing country has led to greater scrutiny over land and forest tenure by social movements and in the international discourse over its national forestry policies (Siscawati et al., 2017).

Conceptually, a customary forest is a forest that is within the territory of customary law communities (article 1(6) PERMENLHK Number P32/2015) and has not been designated as state forest (MK 35). This form of tenure security is considered private/customary forest with the right to control its status. The procedural designation of the customary forest is realized through an application by the customary community itself, reviewed and approved by the Ministry of Environment and Forestry (KLH). To accelerate the process of recognising customary forests, the Ministry has stipulated a replacement for the Ministerial Regulation Number P.32/MENLHKSetjen/2015 concerning private forests, namely Regulation Number P.21/MENLHK/Setjen/Kum. 1/4/2019, dated April 29, 2019 concerning Customary Forests and Private Forests. This was followed by SK. 347/MENLHK/PSKL/PKTHA/KUM.1/5/2019 concerning the Extension of the Working Group for the Acceleration of Designating Customary Forests.

One of the functions of P.21/2019 is as a substitute regulation that guides the implementation of Phase I of Indigenous Forests and Indicative Areas of Indigenous Forests. The mapping of Indigenous Forests and Indigenous Areas of Indigenous Forests Phase I is described in Decree 312/MENLHK/Setjen/PSKL.1/4/2019 concerning Mapping of Customary Forests and Indigenous Areas of Indigenous Forests Phase I (April 29, 2019) until Revision IV. Ministerial Decree Number SK.6394/MENLHK-PKTL/REN/PLA.0/7/2019 PIAPS PROVINSI is intended to ensure that proposals in areas of customary law communities can be stipulated as customary forests. The mapping of customary forests and indicative areas Phase I seeks to guarantee efforts to accelerate the inclusion of customary forests through a verification process at the field level, thereby facilitating the resolution of spatial conflicts with other parties (permit holders, third party claims) while accelerating the issuance of Perda.

The status of customary forests in West Papua, especially the legal umbrella regarding the certainty of the existence of customary forests, both through the Raperdasus and Raperda, is currently still in process, pending review and approval by the national government, as well as draft proposals at the district and city level. The regional legal products (Perdasus, Perda) have recognized the MHAs, but the process of determining the administrative boundaries requires further clarification.

On the other hand, even though customary communities have established institutions, and some have even completed the mapping of customary areas with other parties (e.g., NGOs), they have still not received formal acknowledgement, have not received their customary forest designation, and therefore cannot obtain State recognition of their rights. Even initiatives that aim to provide formal access and support services to indigenous peoples have not been supported by the central government because of the lack of typology (Fatem et al., 2018). Wibowo et al. (2019) explain that a contributing factor is that most regions have not received confirmation through regional regulations or a Regent/Mayor's Decree and therefore cannot continue to the next step because the request lacks specified location and boundaries of their customary territories, as required by Article 24 A No. P.62/Menhut-II/2013. It will be important to find a breakthrough in in these legal stipulations based on the Regent/Governor's Decree, i.e., whether it is necessary in extreme conditions to replace decisions that are easier developed in stages.

\section{Dynamics of Customary Forests of the Parties in West Papua}

Many projects related to customary communities in West Papua have been and are in the process of being implemented, but challenges remain due to limited literacy and socialization of regulations at the site level. The lack of studies on social forestry, especially those related to customary forests, is another major obstacle, especially in-depth studies of indigenous communities using applicable norms, standards, procedures and criteria. This confirms that there are still differences in the concept of social forestry in the formal version of the state and traditional 
communities at the local level where there is such a wide gap (Bong et al., 2019). It is the same as stated by (Toman \& Ashton, 1996) that the gap between knowledge and techniques in the ecological and economic analysis will remain difficult to understand in its dynamics.

The dynamics of customary forests have been widely studied by local universities through collaborative research efforts. These studies are often referenced and reflected in administrative planning documents; however, implementation of these plans is still far from expectations. The Multi-Stakeholder Policy Circle Discussion Forum (FDLKM), convened by the UNIPA Faculty of Forestry, with West Papua development partners and the West Papua Provincial Government, succeeded in identifying and gaining agreement on several recommendations to support the acceleration of the customary forest approval process. The involvement of key stakeholders remains an important element in the practice of forest system management (Toman and Ashton, 1996).

All parties are expected to collaborate in accelerating the customary forest program through existing stages, especially the critical challenge of completing procedures for recognition of indigenous people, including the promulgation of regional legislation (Perda). The main criteria required includes: 1) Characteristics of indigenous peoples; 2) Customary Law Products; 3) Map of customary territory; 4) Customary institutions and governance systems; and 5) Customary assets and/or objects.

At the grassroots level, the long struggle for indigenous recognition and rights promoted by NGOs (e.g., World Wildlife Fund, Samdhana Institute, Paradisea, Bentara Foundation, Panah Papua and others) has continued despite these significant challenges and limitations. In the beginning, may of these NGOs worked relatively independently, based on individual mandates, program priorities, and budgeting cycles. For the future, partnership and funding sustainability require serious attention so that collaboration can be carried out effectively.

Prior to the Constitutional Court's Stipulation 35 of 2012, the village forest program was seen as an intermediary step in preparing for the customary forest scheme, since at that time, the program had not gained official state recognition. This despite the advocacy by indigenous rights activists, especially from the Indigenous Peoples' Alliance (AMAN). Following the Constitutional Court decision, NGOs continued to advocate at the site level. The current distribution of customary forests is largely due to the continuing work of NGOs in Tanah Papua, especially their contributions to the Indicator Map for Customary Areas and Customary Forests. This long-term commitment and collaboration have been essential in accelerating social forestry work, especially the customary forest program.

The assistance of NGO partner organizations and government funding schemes for social forestry programs must maintain a focus on the preparation of documents related to customary forests, especially the process of compiling maps of customary areas. Funding for social forestry projects has been reduced, as it seems that at the provincial level social forestry is not considered a priority program. This is evident in the lack of databases and information on customary territories at the local government level. Therefore, we recommend that provincial and local governments work with partner organizations to conduct thorough ecological and cultural analysis based on emerging research and other references.

In West Papua, the Indigenous Peoples Institution (LMA), created by the government as a representative institution for indigenous peoples, contrasts greatly with the Papua Customary Council (DAP), an independent grassroots organization. It is important to increase local government capacity and seek greater legitimacy for the role of indigenous peoples; however, government should maintain a studied neutrality, not taking sides with expedient political interests, but working instead to maintain the identity and rights of indigenous communities. The ultimate goal is to gain recognition that customary forests located within a legally recognised community are not state forests.

"Talking about forests in Papua is talking about the Papuan people and their customs" (Fatem, 2019). The Papuan concept of customary forests existed long before the Indonesian state came into existence and established legal regulations. State regulations that require indigenous communities to meet these new legal requirements shows the State's hegemonic attitude towards forest resources in Tanah Papua. As a result, social forestry in Tanah Papua, especially the customary forest 
program, has yet to gain full legitimacy from the government and from customary communities themselves. It is therefore necessary to separate the interests of the state from the needs of indigenous people as stewards of natural resources in West Papua.

\section{Conclusion}

Global environmental issues related to sustainable forest management and climate change are inextricably linked with the existence and engagement of local communities. On a national scale, the social forestry program is a manifestation of the state's interest in accommodating the interests and involvement of local communities in forest management. The participation of other stakeholders with various backgrounds and perspectives, from the national state down to the site level, represent different interests in recognition and certainty over customary forests in Papua. The process of establishing customary territories is a major milestone in achieving the ultimate goal of protecting $70 \%$ of forest areas in West Papua under customary community-based management. The limited area of customary forests in West Papua, which only reaches 2,554.2 hectares, is a form of injustice to indigenous communities. Targets for the national social forestry program still focus heavily on the Village Forest program, which currently encompasses 48,631 hectares. The greatest obstacle to accelerating recognition of customary forests in Tanah Papua is the mechanism for making regional regulations, especially given the incomplete mapping of customary territories. Grassroots efforts continue to seek opportunities to mainstream these basic needs. Ultimately, however, these conditions and challenges will require significant political and administrative support, as well as strong support from the communities themselves. Absent this broad agreement, the result could be the emergence of new social conflicts involving indigenous peoples.

Will these efforts address the basic needs of indigenous peoples for thecertainty of rights and access, or will they only strengthen the interests of certain parties working behind the scenes? Various interests - global, national, regional and local - await the final answer for the future of indigenous community-based forest management in Tanah Papua. To achieve these social justice goals, the separation of normative regulations and local needs of indigenous peoples must be clearly defined.

Conflicts of Interest: The authors declare there is no risk of conflict of interest.

Acknowledgements: Thank you for the support from the leadership of the Faculty of Forestry, Papua University and all parties who have contributed and discussed so far. The authors also wish to thank the anonymous reviewers for providing constructive comments to improve this paper.

\section{References}

Arts, B. J. M., Appelstrand, M., Kleinschmit, D., Pülzl, H., Visseren-Hamakers, I. J., Atyi, R. E. A., ... \& Yasmi, Y. (2010). Discourses, actors and instruments in international forest governance. In Embracing complexity: Meeting the challenges of international forest governance. A global assessment report. Prepared by the Global Forest Expert Panel on the International Forest Regime (No. 28, pp. 57-74). International Union of Forest Research Organizations (IUFRO).

Arts, B., van Bommel, S., Ros-Tonen, M., \& Verschoor, G. (Eds.). (2012). Forest People Interfaces: Understanding Community Forestry and Biocultural diversity. Springer Science \& Business Media.https://doi.org/10.3920/978-90-8686-749-3

Awang, S. A. (2009). Deforestasi dan Konstruksi Pengetahuan Pembangunan Hutan Berbasis Masyarakat. Institut Hukum Sumber Daya Alam.

Brearley, F. Q., Adinugroho, W. C., Cámara-Leret, R., Krisnawati, H., Ledo, A., Qie, L., ... \& Webb, C. O. (2019). Opportunities and challenges for an Indonesian forest monitoring network. Annals of forest science, 76(2), 1-12.https://doi.org/10.1007/s13595-019-0840-0

Bong, I. W., Moeliono, M., Wong, G. Y., \& Brockhaus, M. (2019). What is success? Gaps and tradeoffs in assessing the performance of traditional social forestry systems in Indonesia. Forest and Society, 3(1), 1-21. https://doi.org/10.24259/fs.v3i1.5184 
Boo, H.L., dan Wiersum, K.F., 2011. Manajemen Adaptif Sumberdaya Hutan. Penerjemah Dwiko B. Permadi. Datamedia. Yogyakarta

BPS. (2018). STATISTIK INDONESIA 2018.

Cámara-Leret, Rodrigo, Frodin DG, Adema F, Anderson C, Appelhans MS, Argent G, Guerrero SA, Ashton P, Baker WJ, Barfod AS, Barrington D, Borosova R, Bramley GLC, Briggs M, Buerki S, Cahen B, Callmander MW, Cheek M, Cheng-Wei C, Conn BJ, Coode MJE, Darbyshire I, Dawson S, Dransfield J, Drinkell C, Duyfjes B, Ebihara A, Ezedin Z, Long-Fei F, Gideon O, Girmansyah D, Govaerts R, Fortune-Hopkins H, Hassemer G, Hay A, Heatubun CD, Hind DJN, Hoch P, Homot $P$, Hovenkamp P, Hughes $M$, Jebb M, Jennings L, Jimbo T, Kessler M, Kiew R, Knapp S, Lamei $P$, Lehnert M, Lewis GP, Linder HP, Lindsay S, Low TW, Lucas E, Mancera JP, Monro AK, Moore A, Middleton DJ, Nagamasu H, Newman MF, Lughadha EN, Melo PHA, Ohlsen DJ, Pannell CM, Parris B, Pearce L, Penneys DS, Perrie LR, Petoe P, Poulsen AD, Prance GT, Quakenbush JP, Raes N, Rodda M, Rogers ZS, Schuiteman A, Schwartsburd P, P Scotland RW, Simmons MP, Simpson DA, Stevens $P$, Sundue $M$, Testo $W$, Trias-Blasi A, Turner I, Utteridge $T$, Walsingham L, Webber BL, Wei R, Weiblen GD, Weigend M, Weston P, de Wilde W, Wilkie P, Wilmot-Dear CM, Wilson HP, Wood JRI, Li-Bing Z, van Welzen PC. (2020). New Guinea has the world's richest island. Nature 1-5.

Cámara-Leret, R., Schuiteman, A., Utteridge, T., Bramley, G., Deverell, R., Fisher, L. A., McLeod, J., Hannah, L., Roehrdanz, P., Laman, T. G., Scholes, E., de Fretes, Y., \&Heatubun, C. (2019). The Manokwari declaration: Challenges ahead in conserving 70\% of Tanah Papua's forests. Forest and Society, 3(1), 148-151. https://doi.org/10.24259/fs.v3i1.6067

CIFOR, (2017a). Perhutanan Sosial dan Tata Cara Permohonannya. https://www.cifor.org/library/6589/perhutanan-sosial-dan-tata-cara-permohonannya diakses pada tanggal 31 Mei 2021.

CIFOR, (2017b). Bagan Alir Permohonan Hutan Adat Kepada Menteri LHK. diunduh pada https://www.cifor.org/publications/pdf_files/posters/GCS-Tenure/7_HA-Menteri.pdf.

Fatem, S. M., Awang, S. A., Pudyatmoko, S., Sahide, M. A. K., Pratama, A. A., \& Maryudi, A. (2018). Camouflaging economic development agendas with forest conservation narratives: A strategy of lower governments for gaining authority in the re-centralising Indonesia. Land Use Policy, 78(July), 699-710. https://doi.org/10.1016/j.landusepol.2018.07.018

Fatem, S. M. (2019). Connecting social forestry to conservation policies in Tanah Papua. Forest and Society, 3(1), 141-147. https://doi.org/10.24259/fs.v3i1.5865

Harrison, M. E., Ottay, J. B., D'Arcy, L. J., Cheyne, S. M., Anggodo, Belcher, C., Cole, L., Dohong, A., Ermiasi, Y., Feldpausch, T., Gallego-Sala, A., Gunawan, A., Höing, A., Husson, S. J., Kulu, I. P., Soebagio, S. M., Mang, S., Mercado, L., Morrogh-Bernard, H. C., ... Veen, F. J. F. (2020). Tropical forest and peatland conservation in Indonesia: Challenges and directions. People and Nature, 2(1), 4-28. https://doi.org/10.1002/pan3.10060

Kementerian Lingkungan Hidup dan Kehutanan. (2019). Laporan Kinerja 2019.

Maini, J.S. (2003). International dialogue on forests: impact on national policies and practices. In: Teeter L, Cashore B, Zhang D (eds) Forest policy for private forestry - global and regional challenges. $\quad \mathrm{CAB} \quad$ International, Wallingford, pp 9-15. https://doi.org/10.1079/9780851995991.0009

Marshall, A.J., Beehler, B.M., Kartikasar, S.N., (2007). Ekologi Papua, Jakarta: Yayasan Obor Indonesia dan Conservation International.

Maryudi, A., (2015). Rejim Politik Kehutanan International, Yogyakarta: Gadjah Mada University Press.

Matthews, N., \& Missingham, B. (2009). Social accountability and community forest management: The failure of collaborative governance in the wombat forest. Development in Practice, 19(8), 1052-1063. https://doi.org/10.1080/09614520903220800 
O'brien, K., Eriksen, S., Nygaard, L. P., \& Schjolden, A. (2007). Why different interpretations of vulnerability matter in climate change discourses. Climate Policy, 7(1), 7388.https://doi.org/10.1080/14693062.2007.9685639

Pitoyo, A. J., Listyaningsih, U., \& Alfana, M. A. F. (2019). The Livelihood of Non-Resident Households in the Oil and Gas Mining Areas in Papua. IOP Conference Series: Earth and Environmental Science, 256(1), 1-7. https://doi.org/10.1088/1755-1315/256/1/012033

Purnomo, H., (2012). Pemodelan dan simulasi untuk pengelolaan adaptif sumberdaya alam dan lingkungan., Bogor: IPB Press

Ragandhi, A., Hadna, A. H., Setiadi, S., \& Maryudi, A. (2021). Why do greater forest tenure rights not enthuse local communities? An early observation on the new community forestry scheme in state forests in Indonesia. Forest and Society, 5(1), 159-166. https://doi.org/10.24259/fs.v5i1.11723

Rickenbach, M., Zeuli, K., \& Sturgess-Cleek, E. (2005). Despite failure: The emergence of "new" forest owners in private forest policy in Wisconsin, USA. Scandinavian Journal of Forest Research, 20(6), 503-513. https://doi.org/10.1080/02827580500434806

Runtuboi, Y. Y., B. Permadi, D., Sahide, M. A. K., \& Maryudi, A. (2021). Oil Palm Plantations, Forest Conservation and Indigenous Peoples in West Papua Province: What Lies Ahead? Forest and Society, 5(April), 23-31. https://doi.org/10.24259/fs.v5i1.11343

Siscawati, M., Banjade, M. R., Liswanti, N., Herawati, T., Mwangi, E., Wulandari, C., Tjoa, M., \& Silaya, T. (2017). Overview of forest tenure reforms in Indonesia. In Overview of forest tenure reforms in Indonesia. https://doi.org/10.17528/cifor/006402

Toman, M. A., \& Ashton, P. M. S. (1996). Sustainable forest ecosystems and management: A review article. Forest Science, 42(3), 366-377. https://doi.org/10.1093/forestscience/42.3.366

Ungirwalu A, Awang S.A, Maryudi A, Priyono S., 2019. Konstruksi Hutan-Budaya: Skenario pengelolaan sumberdaya alam adaptif hasil hutan bukan kayu (HHBK) Berbasis Masyarakat Adat Di Papua Barat. Disertasi UGM

Wibowo, A., Muhajir, M., \& Nadya, D. (2019). Opini Hukum Peraturan Menteri Nomor P.21/MenlhkSetjen/Kum.1/4/2019 tentang Hutan Adat dan Hutan Hak. 